\title{
Using Probiotics as Supplementation for Helicobacter pylori Antibiotic Therapy
}

\author{
Jianfu Ji and Hong Yang * \\ State Key Laboratory of Microbial Metabolism, School of Life Sciences and Biotechnology, Shanghai Jiao Tong \\ University, Shanghai 201100, China; jijianfu@sjtu.edu.cn \\ * Correspondence: hongyang@sjtu.edu.cn; Tel.: +86-021-34205343
}

Received: 19 December 2019; Accepted: 7 February 2020; Published: 8 February 2020

\begin{abstract}
Helicobacter pylori is a well-known pathogen that is highly prevalent in the world population, and H. pylori infection is potentially hazardous to humans because of its relationship to various gastrointestinal diseases, such as gastric ulcers, chronic gastritis, and gastric carcinoma. Therefore, the clinical guidelines recommend taking antibiotic therapy to eradicate the pathogen, which usually leads to the desired therapeutic effect. However, some failure cases of this therapy indicate that the increasing antibiotic resistance and side effects may affect the therapeutic effect. Here we propose that using probiotics as supplementation for antibiotic therapy may provide an extra help. Recent studies have shown that probiotic supplementation therapy has promising application prospects; it can enhance the antibiotic effect to achieve a better therapeutic result and maintain the balance of the host gastrointestinal microbiota. In summary, under global conditions of increasing H. pylori prevalence, probiotic supplementation therapy is worthy of further studies for future clinical application.
\end{abstract}

Keywords: Helicobacter pylori; probiotic therapy; antibiotic therapy

\section{Introduction}

Helicobacter pylori is a microaerobic, spiral, flagellated Gram-negative pathogen that has colonized approximately $50 \%$ of the world's population yet, the infection rate in China has exceeded $80 \%$ and may continue to increase in the future $[1,2]$. Once $H$. pylori successfully colonized the stomach, it evolves toward persistent chronic infection with spontaneous clearance being relatively rare [3]. Although the majority of infected individuals are clinically asymptomatic, the host can develop gastric ulcers, chronic gastritis or other gastrointestinal diseases, $1-3 \%$ of $H$. pylori-infected people are at risk of developing gastric cancer [4]. Thus, medical guidelines recommend antibiotic therapy as a good option for clinical eradication of $H$. pylori [5]. Recent studies have shown that the eradication of $H$. pylori in infected asymptomatic individuals at all ages can reduce the occurrence of gastric cancer [6]. However, failure cases in this antibiotic therapy indicate that drug-resistant strains and side effects may occur in some patients, which can affect the treatment effect [2,7].

Probiotic supplementation therapy is an emerging therapy for $H$. pylori treatment [8]. Probiotics are defined as live microorganisms which, when administered in adequate amounts, confer a health benefit on the host [9]. Probiotics have natural advantages, such as safety, immunomodulation, and anti-pathogen ability, and are often used to treat gastrointestinal diseases alone or in combination with drugs [10-12]. Most probiotics are deemed to colonize the human gut, and certain species, such as Lactobacillus spp., can colonize the human stomach, directly or indirectly antagonizing H. pylori [13-15]. It has been reported that taking probiotics alone can diminish bacterial load, whereas using probiotics along with antibiotics can improve the eradication rate and alleviate side effects [16,17]. Using probiotics to treat $H$. pylori infection is a feasible way but it shows some uncertainty. The optimal dose, the time 
of dosing, the duration of therapy, and the interaction mechanisms among the selected probiotics and antibiotics remain to be explored [8].

This review summarizes recent studies about the H. pylori infection process, its antibiotic therapy, mechanisms of probiotic therapy, and clinical studies. We highlight the advantages of using probiotics in combination with antibiotics for enhancing antibiotic drug efficacy and restoring the gastrointestinal microbiota. Specific strains can be supplemented during H. pylori clinical treatment to achieve a better antibiotic therapy efficacy. Therefore, this review is instructive for the H. pylori clinical eradication through developing probiotics as an alternative therapy. It is worth noting that the effects of probiotic therapy vary greatly because of strain specificity.

\section{H. pylori Infection and Antibiotic Therapy}

\subsection{Colonization Mechanisms}

H. pylori can cause diseases only if successfully colonized. The optimal growth $\mathrm{pH}$ for $H$. pylori is 8.5, whereas the bacteria can survive for only approximately 30 min under extremely acidic environments, such as gastric cavity $[18,19]$. The ability of $H$. pylori to transiently resist gastric acid and pass through the gastric mucous layer, quickly reaching the $\mathrm{pH}$-neutral environment, mainly depends on its urease, chemotaxis system, flagella, and spiral morphology (Figure 1) [20]. In addition, the capacity for gastric epithelial cell adherence, biofilm formation, and antioxidant enzyme system help H. pylori achieve long-term colonization [20-24].

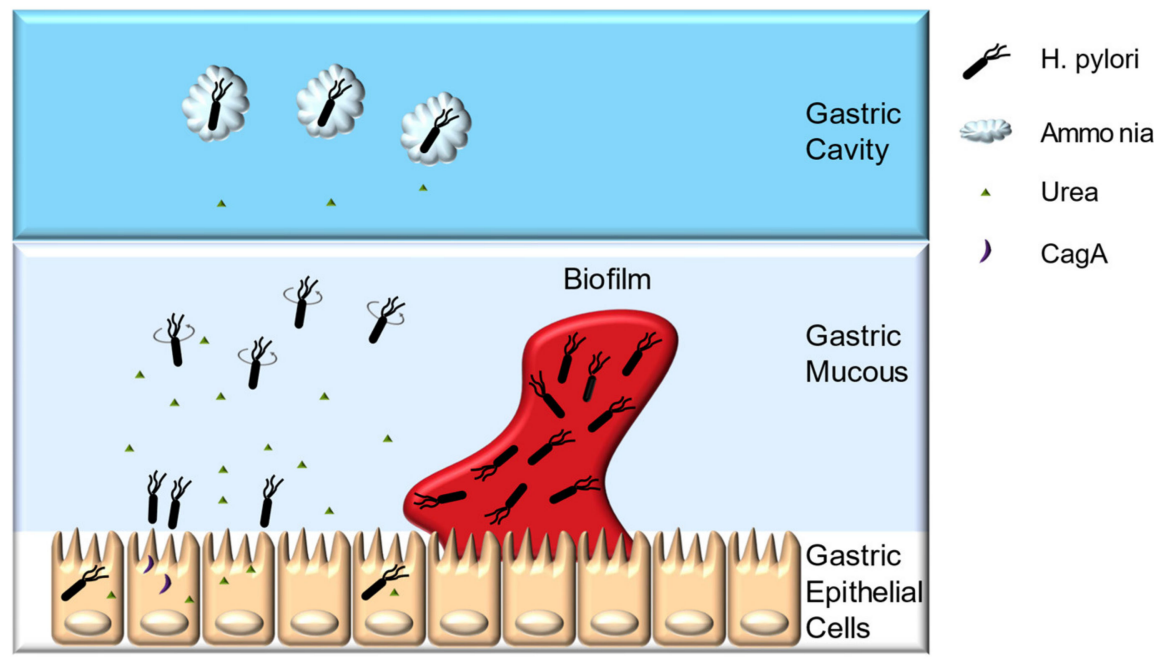

Figure 1. Colonization of the stomach by H. pylori.

H. pylori urease accounts for approximately $10 \%$ of its total protein mass, playing a pivotal role in both establishing initial colonization and maintaining chronic infection $[25,26]$. Urease can hydrolyze urea to produce carbon dioxide and ammonia, and the latter being able to buffer the gastric acids around the bacteria to maintain its viability [26]. Furthermore, the morphology of the gastric mucin is closely related to the $\mathrm{pH}$ value. Gastric mucin forms a gel under low $\mathrm{pH}$, whereas the increase in $\mathrm{pH}$ caused by urease catalysis loosens gastric mucin, enabling $H$. pylori to swim more easily [20].

The chemotaxis system, flagella, and spiral morphology of $H$. pylori enable its swift passage through the gastric mucous layer. Urea is not only the substrate of urease, but also one of the signaling molecules of this chemotaxis system. H. pylori uses chemotaxis system to sense the $\mathrm{pH}$ gradient, urea and amino acids secreted by the host cells to position itself [25,27]. Meanwhile, the chemotaxis system is capable of receiving adversity signals such as reactive oxygen species (ROS), bile salts emitted by host cells, and quorum sensing molecules (autoinducer-2, AI-2) produced by the bacteria itself, thereby driving H. pylori away from the harsh environment [28]. Chemotaxis system integrity is indispensable for $\mathrm{H}$. pylori pathogenesis. McGee et al. reported that the CheY chemotaxis regulator 
deficient H. pylori strain cannot colonize Mongolian gerbils, and the TlpB chemoreceptor-deficient strain can infect Mongolian gerbils with a substantial decrease in inflammation [29]. The flagella and spiral morphology of $H$. pylori facilitate its passage through the gastric mucous layer. H. pylori has polar flagella with rotation that is powered by the motor proteins MotA and MotB, and mutants with incomplete flagella has a reduced ability to infect mice gastric, whereas mutants with more flagella number can swim faster through simulated gastric mucous layer [30,31]. Spiral morphology enables H. pylori to drill through the gastric mucous layer like a rotating cork, mutants with straight-rod morphology will lose about $7-21 \%$ of its swimming speed [25,31].

After passing through the gastric mucous layer, $H$. pylori can persistently colonize the space between the gastric mucous layer and gastric epithelial cells, mainly relies on its abilities of epithelial cell adherence and invasion, biofilm formation, and its antioxidant enzyme system. H. pylori encode approximately 30 outer membrane proteins (OMPs), such as blood group antigen-binding adhesion (BabA), and sialic acid-binding adhesion (SabA). These OMPs can bind to the recognition sites on gastric epithelial cells, providing a basis for long-term colonization [25]. Successfully colonized H. pylori can invade host epithelial cells and immune cells under unfavorable conditions [32]. It has been confirmed that $H$. pylori can invade and proliferate in gastric epithelial cells such as AGS and MKN45 cells, which may enable them to avoid the host immune system [32]. Moreover, H. pylori can form biofilms in gastric mucosa, and biofilm formation might enhance its resistance to drugs and the host immune system [21-24,33]. In vitro experiments have shown that the resistance of H. pylori ATCC43629 biofilm cells to clarithromycin is approximately eight-fold greater than that of planktonic cells [34]. Additionally, biofilm formation increases $H$. pylori TK1402 generation rates of drug-resistance mutations and its resistance to metronidazole, clarithromycin, and amoxicillin in vitro [22,24,35]. The antioxidant system is another defense mechanism of $H$. pylori. These bacteria resist the oxidative stress generated by the host immune response by invoking its own antioxidant enzymes, such as superoxide dismutase (SOD) and hydrogen peroxide (CAT) [36-38]. The infection rate of the SOD-deficient strain in mice is only $4 \%$, whereas for the wild-type strain is as high as $88 \%$, indicating the importance of antioxidant enzymes in H. pylori infection [39].

\subsection{H. pylori Pathogenesis}

Although about $85 \%$ of colonized individuals are asymptomatic or have mild gastritis, $15 \%$ of infected people still have a chance to develop peptic ulcer disease (PUD) during the long-term H. pylori infection, and about $1 \%$ can develop gastric cancers [40]. After successful colonization of the stomach, these bacteria can activate host's innate and adaptive immune response, which may induce atrophic gastritis, dysplasia, metaplasia, and ultimately gastric carcinoma [41]. Recent studies have shown that the eradication of $H$. pylori in infected asymptomatic individuals at all ages can reduce the occurrence of gastric cancers [6]. Various virulence factors and virulence genes of H. pylori, such as cytotoxin-associated gene A protein (CagA), vacuolating cytotoxin protein (VacA), duodenal ulcer promoting gene (DupA), and urease play the key role in injuring host tissues and inducing gastrointestinal diseases [19].

CagA is an oncogenic protein encoded by $c a g A$ gene located at the end of cag pathogenic island (cagPAI), it is closely related to the occurrence of gastric adenocarcinomas and PUD [42]. After being injected into host cells through a type IV secretion system, CagA can interact with multiple host cell molecules, thus altering the intracellular signal transduction pathways of gastric epithelial cells to induce pro-inflammatory responses, leading to chronic inflammation of gastric mucosa. Meanwhile, CagA can facilitate carcinogenesis through the modulation of apoptosis, disruption of cell polarity, and promotion of genetic instability [43]. Apoptosis of gastric epithelial cells causes a decrease in gastric acid secretion and creates a more conducive environment for the H. pylori growth [44]. Studies show that individuals infected with cag $A$-positive $H$. pylori strains are associated with two-fold higher risk of distal gastric cancers and 1.69-fold risk of PUD compared to those infected with cagA-negative strains [40]. 
VacA toxin exists in most $H$. pylori strains, but varies greatly in its toxin activity. It is named after its ability to form "vacuoles" in gastric epithelial cell cytoplasm $[19,45]$. VacA have been described as a multi-receptor protein with receptors being found on the surface of various cells, including gastric epithelial cells, and immune cells [46]. After binding to these receptors, VacA can enter the host cells and accumulate inside different cellular compartment to induce membrane depolarization, mitochondrial dysfunction, autophagy, activation of mitogen-activated protein kinases, inhibition of $\mathrm{T}$ cell function, and cell apoptosis [42,47]. Studies show that individuals infected with $H$. pylori harboring vacA s1 or $\mathrm{m} 1$ have an increased risk of gastric cancer in Western populations, while vacA i1 type $H$. pylori infection is associated with higher gastric cancer risk in the Middle Asia and Middle East area [40].

DupA is named for its ability to increase the occurrence of duodenal ulcer (DU) [40]. The prevalence of this gene was higher in strains from patients with duodenal ulcer than in those with gastritis or gastric cancer [48]. Data analysis have shown that individuals carrying dupA-positive strains are under increased risk for duodenal ulcers and gastric cancers [43].

In addition, $H$. pylori urease and its catalytic products may cause direct damage to host tissues. Ammonium ions can destroy the integrity of the connection between gastric epithelial cells, while carbon dioxide supports bacteria resistance to damage from nitric oxide metabolites and peroxynitrite produced by phagocytic cells [26]. Urease also induces inflammation and angiogenesis in vivo independently of its catalytic activity and directly activates human neutrophils to produce reactive oxygen species, thereby injuring the host body [49].

\subsection{Antibiotic Therapy}

Antibiotic therapy is the most effective and widely used treatment for $H$. pylori infection. Antibiotics with significant anti- $H$. pylori effects in vitro tends to be unstable in the extremely acidic environment in human stomach, thus being difficult to maintain high concentrations to kill the bacteria, leading to a poor clinical effect [50]. Antibiotics with good acid resistance and bactericidal effects, such as metronidazole, clarithromycin, and amoxicillin, are the most commonly used drugs in H. pylori clinical therapy [51]. In addition, one antibiotic alone cannot eradicate the bacteria thoroughly, therefore multiple drug therapies are recommended [52]. Most commonly used antibiotic therapy, triple therapy, is based on the combination of two antibiotics plus one proton pump inhibitor (PPI), with a duration of 7-14 days [50]. The antibiotics play a major role in eradicating the pathogen, while the PPI acts to inhibit gastric acid secretion and thus enhance the effect of the antibiotics [53].

Triple therapy was considered the most effective therapy for H. pylori eradication in the past, however the increase in drug-resistant strains over the years has changed this situation [54,55]. It has been reported that the resistance rate of $H$. pylori to metronidazole in China increased by approximately $50 \%$ between 2000 and 2014, and clarithromycin resistance has increased from approximately $14.8 \%$ in 2000 to approximately $52.6 \%$ in 2014 [2]. Traditional triple therapy based on metronidazole and clarithromycin tends to have an eradication rate below $80 \%$, which no longer meets the clinical need [8]. The increase in antibiotic-resistance strains poses a severe challenge for $H$. pylori treatment, and therefore, enhancing the efficacy of old antibiotics or developing new antibiotics is currently considered feasible solutions.

Another challenge for the antibiotic therapy of H. pylori are side effects. These may occur in some patients, the combination of two antibiotics causes more damage to the host gastrointestinal microbiota and leads to the imbalanced microbial population associated with the proliferation of gastrointestinal pathogens [56-58]. Additionally, PPI induction decreases in gastric acid secretion may increase the mobility of these pathogens, enable them to circulate in the gastrointestinal tract $[59,60]$. Side effects occur in those patients may cause a decline in treatment efficiency and make retreatment difficult. 


\section{Probiotic Therapy}

\subsection{Antagonistic Mechanism}

As an emerging adjuvant, probiotics have been used to treat a series of gastrointestinal diseases, including $H$. pylori infection. In vitro experiments demonstrated that various probiotics have the potential to antagonize $H$. pylori through their metabolites or bacterial cells [61-63]. Sun et al. found four Lactobacillus strains isolated from fermented foods in northeastern China were able to inhibit the growth of H. pylori [63]. The acid-resistant strain L. johnsonii No.1088, isolated from gastric juice of healthy volunteers could suppress H. pylori both in vitro and in a mouse model, and the heat-killed form of the strain also showed antibacterial effects [64,65]. The antagonism of probiotics against H. pylori is achieved through a series of direct or indirect interactions, including secreting antibacterial substances, competing inhibition, enhancing mucous barriers, and regulating immunity (Figure 2) [41].

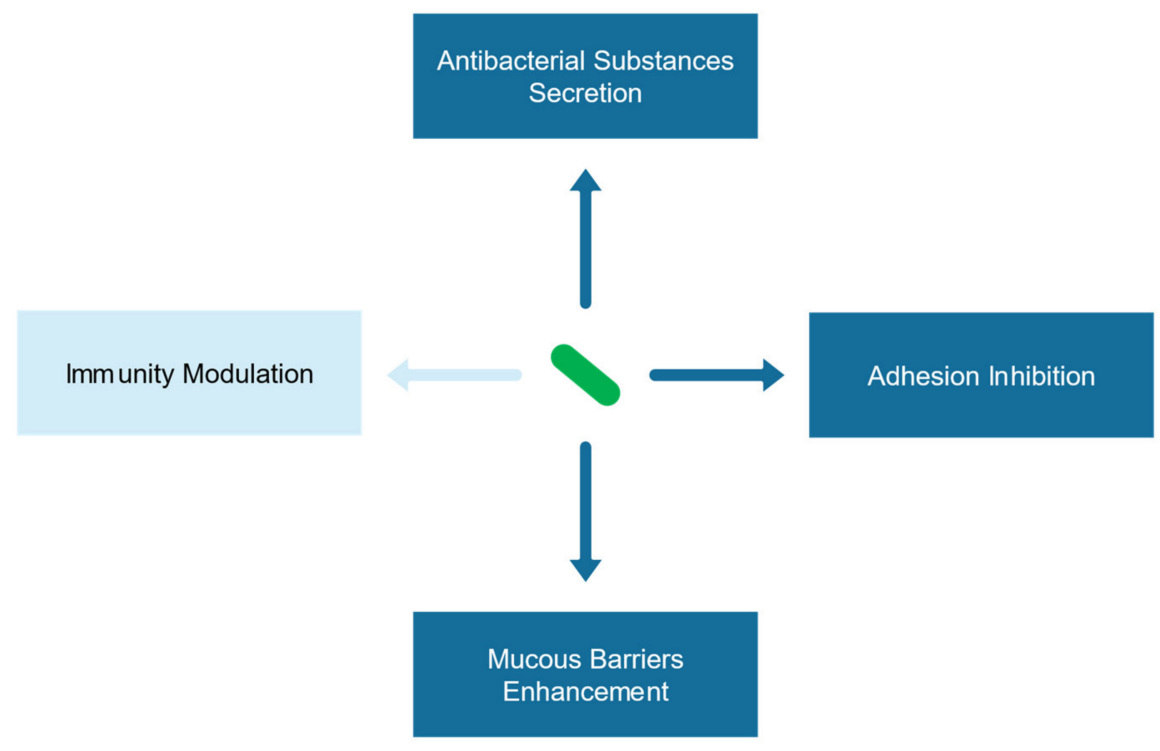

Figure 2. Antagonistic mechanism of probiotic against $H$. pylori.

Probiotics can secrete antibacterial substances such as lactic acid, short-chain fatty acids (SCFAs), hydrogen peroxide, and bacteriocin [16]. Lactic acid and short-chain fatty acids normally show more intensive antibacterial ability than strong acids because of their incomplete ionization, the undissociated form of these organic acids can damage $H$. pylori cells by functioning as proton carriers that induce acidification of the cytoplasm and the accumulation of toxic anions [66]. Zheng et al. conducted an in vitro study on L. pentosus LPS16, and found that lactic acid can inhibit both drug-sensitive and drug-resistant $H$. pylori strains [67]. Meanwhile, lactic acid can suppress $H$. pylori urease activity [68]. In addition to organic acids, hydrogen peroxide produced by probiotics can cause oxidative damage to pathogenic proteins, membrane lipids and DNA by forming peroxygen ions, thus injuring the $H$. pylori cell [69]. Furthermore, certain probiotics can produce bacteriocins that have a direct antibacterial effect on H. pylori. Most bacteriocins are thermostable peptides with antagonistic activity against planktonic cells and/or biofilm cells [70]. Among seven bacteriocins derived from lactic acid bacteria, lacticin A164 and BH5 secreted by Lactococcus lactis showed the greatest effectiveness against H. pylori ATCC43504 and DSM [71]. Boyanova et al. found that the bacteriocin secreted by seven L. bulgaricus strains not only inhibited the growth of antibiotic-sensitive H. pylori strains, but also the antibiotic-resistant strains [72]. In addition to these peptide-like bacteriocins, a nonpeptide antipathogen substance synthesized by $L$. reuteri, called reuterin, can inhibit $H$. pylori growth and downregulate the expression of the virulence genes vacA and flaA [73]. 
Probiotics may hinder H. pylori colonization by competing for binding sites or disturbing the adhesion process. Probiotics with high affinity for epithelial cells can block the colonization of pathogenic bacteria in gastrointestinal epithelial cells. It has been shown that L. reuteri JCM1081, TM105 can compete with $H$. pylori for the asialo-GM1 and sulfatide binding sites in gastric epithelial cells, thereby inhibiting early H. pylori colonization [74]. Two L. gasseri strains can affect H. pylori colonization by inhibiting the expression of $H$. pylori adhesion gene sabA [75]. Saccharomyces boulardii has neuraminidase activity selective for $\alpha(2,3)$-linked sialic acid of host cell, thus removes H. pylori binding sites [76].

The enhancement of the mucous barrier by probiotics helps the host to hinder $H$. pylori colonization. H. pylori infection can downregulate the expression of muc1 and muc5AC gene in KATO III cells, which may cause mucous layer disruption in vivo [77]. Probiotics can upregulate tight-junction proteins and promote the mucous secretion by increasing the expression of $m u c 1, m u c 2$, and $m u c 3$, thus stabilizing the mucous layer [78]. These properties indicate that the host body may better resist $H$. pylori invasion by relying probiotics on repairing the gastric mucosal barrier, effectively preventing the initial infection and reinfection of the pathogen.

In addition to these nonimmune effects, probiotics can alleviate the host inflammation caused by $H$. pylori infection. H. pylori infection-induced inflammatory diseases are associated with the sustained expression of inflammatory factors, and these factors do not eliminate $H$. pylori but lead to the continuation of the inflammatory response [79]. Probiotics can inhibit pro-inflammatory factor expression, thereby mitigating the inflammatory response. Numerous studies have shown that probiotic strains such as L. acidophilus, L. bulgaricus, and L. rhamnosus can reduce the expression of IL-8 in $H$. pylori-infected cells $[17,61,80]$. Yang et al. demonstrated that although $H$. pylori infection causes the overexpression of IL-8, TNF- $\alpha$ and other pro-inflammatory factors in MKN45 cells, pretreatment with high doses of L. acidophilus La5 can silence the Smad7 and NF-kB pathways, thus relieving the inflammatory response [79]. Therefore, probiotics have a preventive and mitigating effect on the inflammation caused by H. pylori infection.

\subsection{Clinical Studies}

The use of probiotics alone or in combination with antibiotics has been reported in many clinical trials. Specific probiotic therapy not only improves the eradication rate but also reduces the side effects caused by antibiotic therapy [81]. Gotteland et al. categorized 182 asymptomatic children with $H$. pylori infection into four groups, namely, the triple therapy group, S. boulardii plus inulin group, L. acidophilus LB group, and drug-free group. The results showed that the level of H. pylori in infected children in the S. boulardii plus inulin group reduced, and that as many as $12 \%$ of the children achieved pathogen eradication [82]. Another study claimed that L. reuteri combined with PPI could provide approximately $12.5 \%$ eradication rate without the use of antibiotics [9]. Although the use of probiotics alone has some effect, this approach does not meet the clinical needs, and use of probiotics as auxiliary in antibiotic therapy achieves greater significant effects [51]. Fonseca et al. analyzed the results from ten clinical trials involving antibiotic therapy supplemented with different L. reuteri strains and all the antibiotic-probiotic combination groups exerted greater eradication effects than was realized with the single antibiotic group, with the exception of one study [83]. Sýkora et al. treated 86 children with $H$. pylori infection and found that the eradication rate from the use of L. casei DN114001 along with triple therapy was $84.6 \%$, while for the triple therapy group alone, it was $57.5 \%$, and probiotic supplementation reduced the severity of the side effects simultaneously [84]. Probiotic supplementation therapy can improve not only the eradication rate of antibiotic-sensitive $H$. pylori strains but also that of the resistant strains. For clarithromycin-resistant strains, use of L. lactis OLL2716 in combination with triple therapy increased the eradication rate by approximately $10 \%$ compared to that of the single triple therapy [85]. Furthermore, fermented milk preparation containing multiple probiotics also improves the eradication rate of triple therapy by $5-15 \%$ [86]. 
However, some reports claim that the use of probiotics in clinical treatment exerts no significant effects [87]. We deem these failure may be related to the selected probiotic species and/or antibiotic class. Only the correct probiotic strain applied in the appropriate manner will lead to therapy that achieves the desired therapeutic effect.

\section{Advantages of Probiotic Supplementation Therapy}

\subsection{Drug Synergy and Mutant Prevention Theories}

The range of drug concentrations for which drug-resistant mutants are most readily induced is called the mutant selection window and it extends from the minimum inhibitory concentration (MIC) to the mutant prevention concentration (MPC) [88]. When the drug concentration is within the mutant selection window, the growth of drug-sensitive strains is inhibited, whereas the proportion of resistant strains increases [89]. Although taking a low dose of drugs does not lead to a high incidence of resistant strains, it does not achieve good clinical effects, and increasing the dose might eradicate the pathogen with aggravating side effects. Multiple drug combinations can better resolve these issues [90-93]. According to drug synergy theory, multiple drugs used together do not yield a simple effect of $1+1=2$; they may have a synergistic or antagonistic effect [92]. Synergistic effects can improve drug efficacy and prevent the emergence of drug-resistant bacteria because of the difficulty in producing multiple drug mutants [93]. Thus, using synergistic drugs for H. pylori treatment can decrease MPC and minimize the mutant selection window to achieve better efficacy and prevent an increase in drug-resistant bacteria. The synergistic effect is not limited to antibiotics, antibiotics and non-antibiotic adjuvants also have synergistic effects [90].

Although most probiotics are localized in the gut, certain probiotics can colonize the $\mathrm{pH}$-neural part of the stomach $[13,14]$. Substances metabolized by these strains may have the potential to act synergistically with antibiotics. In vitro experiments have shown that the combination of tetracycline and probiotic fermentation broth has greater antimicrobial effects against $P$ seudomonas aeruginosa clinical resistant strains than either tetracycline or probiotic fermentation broth does alone [94]. Yang et al. conducted an antibacterial study on Clostridium difficile, and the results showed that Bifidobacterium breve YH68 cell-free supernatant can enhance the synergistic effect of antibiotics and weaken the antagonistic effect [95]. Consequently, a combination of probiotic metabolites and antibiotics can have a greater antibacterial effect against either Gram-negative or Gram-positive pathogens. Although there are a few in vitro studies on $\mathrm{H}$. pylori to confirm the synergy between probiotics and antibiotics, the positive clinical results hint at a potential interaction.

\subsection{Biofilm Theory}

Biofilms are bacterial populations that adhere to each other or the surface of a medium, containing viscous and protective substrates, and can thus transfer nutrients to internal bacteria and excrete detrimental metabolites by forming channels to improve bacterial resistance to hostile environments [96]. Recent studies confirmed that $H$. pylori has the ability to form biofilms both in vitro and in vivo and the biofilm formation may play a pivotal role in long-term colonization and related gastrointestinal diseases [21,97]. Coticchia et al. analyzed the gastric mucosa of $H$. pylori urease-positive and urease-negative populations, and the results revealed that the average coverage of the biofilms in the gastric mucosa was $97.3 \%$ in the urease-positive patients, while in the urease-negative patients, it was only $1.64 \%$ [33]. These results suggest the prevalence of $H$. pylori biofilms in the human gastric mucosa. Moreover, in vitro experiments showed that H. pylori clinical strains TK1402 and TK1049 could increase the tolerance to clarithromycin, amoxicillin, and metronidazole after biofilm formation [24]. The drug-tolerance conferred by biofilms may depend on the overexpression of drug efflux pumps or an increased rate of antibiotic resistance mutations $[23,35,98]$. The formation of $H$. pylori biofilms may also create defenses against the host immune system $[21,99,100]$. 
Considering $H$. pylori biofilms and the greater antibiotic resistance they confer, destroying the biofilm to enable the administration of a reduced antibiotic dose is a new strategy for $H$. pylori treatment [33]. Cammarota et al. separated 40 infected patients with $H$. pylori eradication failure into two groups for retreatment. The control group was given antibiotic therapy only, and the experimental group was given the anti-biofilm agent $N$-acetylcysteine before antibiotic therapy. The cure rate of the experimental group was $65 \%$, while that the control group was only $20 \%$, and the biofilm was found only in the infected individuals with failed eradicate again upon retreatment [101]. The results suggest that the use of an anti-biofilm preparation along with antibiotics may result in better clinical treatments. Although there are few direct reports of probiotics use against $H$. pylori biofilm, reports have confirmed that probiotics can destroy the mature biofilms of pathogenic bacteria, such as Enterococcus faecalis and Staphylococcus aureus [102-105]. In addition, the bacteriocin secreted by L. brevis can inhibit Escherichia coli and Salmonella typhimurium biofilm formation [70]. These findings indicate that probiotics are likely to have a killing effect on $H$. pylori biofilm, and the destruction of these biofilms may improve the effect of the antibiotics, thereby achieving better eradication effects while reducing the clinical dose of antibiotics necessary.

\subsection{Gastrointestinal Theory}

The human gastrointestinal microbiota theory suggests that gastrointestinal microbes and their metabolites can modulate human physiological activities, such as nutrient absorption, energy metabolism and immune function, and the bacteria, host, and environment are interdependent and mutually constrained in a dynamic balance [15,106-109]. H. pylori infection alters both the gastric and intestinal microflora [110]. At the same time, the bactericidal effect of antibiotic use and the $\mathrm{pH}$ change caused by PPI can lead to more severe disorders [56-60]. Clinical studies have confirmed that $H$. pylori infection reduces the diversity of the stomach microbiota in children and adults, and this microbiota may not be restored after eradicating the pathogen $[15,111]$. The evidence from an analysis of the gastric microbiota of infected people and noninfected people revealed that the abundance of Proteobacteria and Spirochetes in the former is higher than that of the latter [15]. In mouse model, H. pylori infection changes the intestinal relative microbial abundance in an indirect way based on the fact that the bacteria has not been detected in mice feces [110]. Furthermore, antibiotic eradication therapy create additional changes in the gastrointestinal microbiota. Lactobacillus spp.in the stomach dramatically decreased after penicillin was administered to a mouse model [15]. In an infected population treated with quadruple therapy, the alpha diversity and B. adolescentis abundance in the gut microbiota was significantly decreased, and some E. faecalis strains acquired even greater antibiotic resistance [57]. Intake of probiotics may produce positive effects in terms of protecting and recovering the gastrointestinal microbiota [112].

Experiments with animal models and clinical trials have shown positive effects of probiotics on the host gastrointestinal microbiota. After treatment with L. rhamnosus GMNL-74 or L. acidophilus GMNL-185, the abundance of Bifidobacterium spp. and Akkermansia muciniphilia in H. pylori-infected mice was significantly increased [61]. Wu et al. found that the diversity of the gut microbiota is remarkably reduced when $\mathrm{H}$. pylori infected individuals are treated with triple therapy alone, while supplementation with Bacillus subtilis and E. faecalis can inhibit this reduction [56]. Moreover, colonization of specific probiotics in gastric likely maintain the balance of the gastric microbiota [15]. Therefore, probiotic supplementation is effective for maintaining both the gastric and gut microflora during $H$. pylori infection and antibiotic therapy.

\section{Outlook}

Because of the high prevalence of H. pylori infection and its correlation with gastrointestinal diseases, eradicating the pathogen is certainly a good solution for clinical treatment $[5,113]$. The current clinical use of antibiotic-related therapies is a great option but may be insufficient in some patients. Probiotic supplementation therapy has been clinically proven to enhance the efficacy 
of antibiotics, maintain the host gastrointestinal microflora, and reduce side effects. However, it is difficult to determine which probiotics are most effective in H. pylori treatment based on the existing studies, and different combinations of probiotics and antibiotics can produce unparallel effects. Therefore, relevant experiments should be conducted as theoretical support to explore the selection and appropriate dosage of probiotics and antibiotics to enhance antibiotic efficacy. In addition, the synergistic effect of probiotics and antibiotics should be leveraged not only to target the planktonic bacteria cells but also to induce a corresponding effect on the stubborn biofilm cells and thus prevent repeated infection. Finding the optimal combination of probiotics and antibiotics will promote the effectiveness of the first-line treatment of $H$. pylori by reducing the dosage of the antibiotics needed and the occurrence of side effects during treatment, thus achieving the maximum killing effect on this pathogen.

Author Contributions: Conceptualization, J.J.; investigation, J.J.; resources, J.J.; writing—original draft preparation, J.J.; writing—review and editing, H.Y.; visualization, J.J.; supervision, H.Y.; project administration, H.Y.; funding acquisition, H.Y. All authors have read and agreed to the published version of the manuscript.

Funding: This work was funded by Shanghai Industry-University Joint Research Program, grant number HUCXY-2016-010.

Acknowledgments: The authors would like to thank Jingpeng Yang, Jingfang Du, Fang Jin, Tongtong Liu and Yanting Zhong from Shanghai Jiao Tong University for providing suggestions.

Conflicts of Interest: The authors declare no conflict of interest.

\section{References}

1. O'Connor, A.; O'Morain, C.A.; Ford, A.C. Population screening and treatment of Helicobacter pylori infection. Nat. Rev. Gastroenterol. Hepatol. 2017, 14, 230-240. [CrossRef]

2. Thung, I.; Aramin, H.; Vavinskaya, V.; Gupta, S.; Park, J.Y.; Crowe, S.E.; Valasek, M.A. Review article: The global emergence of Helicobacter pylori antibiotic resistance. Aliment. Pharmacol. Ther. 2016, 43, 514-533. [CrossRef]

3. Pacifico, L.; Osborn, J.F.; Bonci, E.; Romaggioli, S.; Baldini, R.; Chiesa, C. Probiotics for the treatment of Helicobacter pylori infection in children. World J. Gastroenterol. 2014, 20, 673-683. [CrossRef]

4. Bernardini, G.; Figura, N.; Ponzetto, A.; Marzocchi, B.; Santucci, A. Application of proteomics to the study of Helicobacter pylori and implications for the clinic. Expert Rev. Proteom. 2017, 14, 477-490. [CrossRef]

5. Malfertheiner, P.; Megraud, F.; O'Morain, C.A.; Gisbert, J.P.; Kuipers, E.J.; Axon, A.T.; Bazzoli, F.; Gasbarrini, A.; Atherton, J.; Graham, D.Y.; et al. Management of Helicobacter pylori infection-the Maastricht V/Florence consensus report. Gut 2017, 66, 6-30. [CrossRef] [PubMed]

6. Bae, S.E.; Choi, K.D.; Choe, J.; Kim, S.O.; Na, H.K.; Choi, J.Y.; Ahn, J.Y.; Jung, K.W.; Lee, J.; Kim, D.H.; et al. The effect of eradication of Helicobacter pylori on gastric cancer prevention in healthy asymptomatic populations. Helicobacter 2018, 23, e12464. [CrossRef]

7. Dang, Y.; Reinhardt, J.D.; Zhou, X.; Zhang, G. The effect of probiotics supplementation on Helicobacter pylori eradication rates and side effects during eradication therapy: A meta-analysis. PLoS ONE 2014, 9, e111030. [CrossRef] [PubMed]

8. Chey, W.D.; Leontiadis, G.I.; Howden, C.W.; Moss, S.F. ACG Clinical Guideline: Treatment of Helicobacter pylori Infection. Am. J. Gastroenterol. 2017, 112, 212-239. [CrossRef] [PubMed]

9. Dore, M.P.; Bibbò, S.; Pes, G.M.; Francavilla, R.; Graham, D.Y. Role of probiotics in Helicobacter pylori eradication: Lessons from a study of Lactobacillus reuteri strains DSM 17938 and ATCC PTA 6475 (Gastrus ${ }^{\circledR}$ ) and a proton-pump inhibitor. Can. J. Infect. Dis. Med. Microbiol. 2019, 2019, 3409820. [CrossRef]

10. Yang, J.; Yang, H. Non-antibiotic therapy for Clostridioides difficile infection: A review. Crit. Rev. Clin. Lab. Sci. 2019, 56, 493-509. [CrossRef]

11. Yang, J.; Yang, H. Antibacterial Activity of Bifidobacterium breve Against Clostridioides difficile. Front. Cell. Infect. Microbiol. 2019, 9, 288. [CrossRef] [PubMed]

12. Losurdo, G.; Cubisino, R.; Barone, M.; Principi, M.; Leandro, G.; Ierardi, E.; Di Leo, A. Probiotic monotherapy and Helicobacter pylori eradication: A systematic review with pooled-data analysis. World J. Gastroenterol. 2018, 24, 139-149. [CrossRef] [PubMed] 
13. Francavilla, R.; Lionetti, E.; Castellaneta, S.P.; Magistà, A.M.; Maurogiovanni, G.; Bucci, N.; De Canio, A.; Indrio, F.; Cavallo, L.; Ierardi, E.; et al. Inhibition of Helicobacter pylori infection in humans by Lactobacillus reuteri ATCC 55730 and effect on eradication therapy: A pilot study. Helicobacter 2008, 13, 127-134. [CrossRef] [PubMed]

14. Ryan, K.A.; Jayaraman, T.; Daly, P.; Canchaya, C.; Curran, S.; Fang, F.; Quigley, E.M.; O'Toole, P.W. Isolation of lactobacilli with probiotic properties from the human stomach. Lett. Appl. Microbiol. 2008, 47, 269-274. [CrossRef]

15. Espinoza, J.L.; Matsumoto, A.; Tanaka, H.; Matsumura, I. Gastric microbiota: An emerging player in Helicobacter pylori-induced gastric malignancies. Cancer Lett. 2018, 414, 147-152. [CrossRef]

16. Homan, M.; Orel, R. Are probiotics useful in Helicobacter pylori eradication? World J. Gastroenterol. 2015, 21, 10644-10653. [CrossRef]

17. Song, H.; Zhou, L.; Liu, D.; Ge, L.; Li, Y. Probiotic effect on Helicobacter pylori attachment and inhibition of inflammation in human gastric epithelial cells. Exp. Ther. Med. 2019, 18, 1151-1562. [CrossRef]

18. Schreiber, S.; Bucker, R.; Groll, C.; Azevedo-Vethacke, M.; Garten, D.; Scheid, P.; Friedrich, S.; Gatermann, S.; Josenhans, C.; Suerbaum, S. Rapid loss of motility of Helicobacter pylori in the gastric lumen In Vivo. Infect. Immun. 2005, 73, 1584-1589. [CrossRef]

19. Liu, Q.; Meng, X.; Li, Y.; Zhao, C.-N.; Tang, G.-Y.; Li, S.; Gan, R.-Y.; Li, H.-B. Natural Products for the Prevention and Management of Helicobacter pylori Infection. Compr. Rev. Food Sci. Food Saf. 2018, 17, 937-952. [CrossRef]

20. Salama, N.R.; Hartung, M.L.; Muller, A. Life in the human stomach: Persistence strategies of the bacterial pathogen Helicobacter pylori. Nat. Rev. Microbiol. 2013, 11, 385-399. [CrossRef]

21. Hathroubi, S.; Servetas, S.L.; Windham, I.; Merrell, D.S.; Ottemann, K.M. Helicobacter pylori biofilm formation and its potential role in pathogenesis. Microbiol. Mol. Biol. Rev. 2018, 82, e00001-e00018. [CrossRef] [PubMed]

22. Yonezawa, H.; Osaki, T.; Kamiya, S. Biofilm formation by Helicobacter pylori and its involvement for antibiotic resistance. BioMed Res. Int. 2015, 2015, 914791. [CrossRef] [PubMed]

23. Attaran, B.; Falsafi, T.; Ghorbanmehr, N. Effect of biofilm formation by clinical isolates of Helicobacter pylori on the efflux-mediated resistance to commonly used antibiotics. World J. Gastroenterol. 2017, 23, 1163-1170. [CrossRef] [PubMed]

24. Yonezawa, H.; Osaki, T.; Hojo, F.; Kamiya, S. Effect of Helicobacter pylori biofilm formation on susceptibility to amoxicillin, metronidazole and clarithromycin. Microb. Pathog. 2019, 132, 100-108. [CrossRef]

25. Keilberg, D.; Ottemann, K.M. How Helicobacter pylori senses, targets and interacts with the gastric epithelium. Environ. Microbiol. 2016, 18, 791-806. [CrossRef]

26. Debowski, A.W.; Walton, S.M.; Chua, E.-G.; Tay, A.C.-Y.; Liao, T.; Lamichhane, B.; Himbeck, R.; Stubbs, K.A.; Marshall, B.J.; Fulurija, A.; et al. Helicobacter pylori gene silencing In Vivo demonstrates urease is essential for chronic infection. PLoS Pathog. 2017, 13, e1006464. [CrossRef]

27. Huang, J.Y.; Sweeney, E.G.; Sigal, M.; Zhang, H.C.; Remington, S.J.; Cantrell, M.A.; Kuo, C.J.; Guillemin, K.; Amieva, M.R. Chemodetection and destruction of host urea allows Helicobacter pylori to locate the epithelium. Cell Host Microbe 2015, 18, 147-156. [CrossRef]

28. Johnson, K.S.; Ottemann, K.M. Colonization, localization, and inflammation: The roles of H. pylori chemotaxis In Vivo. Curr. Opin. Microbiol. 2018, 41, 51-57. [CrossRef]

29. McGee, D.J.; Langford, M.L.; Watson, E.L.; Carter, J.E.; Chen, Y.T.; Ottemann, K.M. Colonization and inflammation deficiencies in Mongolian gerbils infected by Helicobacter pylori chemotaxis mutants. Infect. Immun. 2005, 73, 1820-1827. [CrossRef]

30. Ottemann, K.M.; Lowenthal, A.C. Helicobacter pylori uses motility for initial colonization and to attain robust infection. Infect. Immun. 2002, 70, 1984-1990. [CrossRef]

31. Martínez, L.E.; Hardcastle, J.M.; Wang, J.; Pincus, Z.; Tsang, J.; Hoover, T.R.; Bansil, R.; Salama, N.R. Helicobacter pylori strains vary cell shape and flagellum number to maintain robust motility in viscous environments. Mol. Microbiol. 2016, 99, 88-110. [CrossRef] [PubMed]

32. Huang, Y.; Wang, Q.L.; Cheng, D.D.; Xu, W.T.; Lu, N.H. Adhesion and invasion of gastric mucosa epithelial cells by Helicobacter pylori. Front. Cell Infect. Microbiol. 2016, 6, 159. [CrossRef] [PubMed] 
33. Coticchia, J.M.; Sugawa, C.; Tran, V.R.; Gurrola, J.; Kowalski, E.; Carron, M.A. Presence and density of Helicobacter pylori biofilms in human gastric mucosa in patients with peptic ulcer disease. J. Gastrointest. Surg. 2006, 10, 883-889. [CrossRef] [PubMed]

34. Bugli, F.; Palmieri, V.; Torelli, R.; Papi, M.; De Spirito, M.; Cacaci, M.; Galgano, S.; Masucci, L.; Paroni Sterbini, F.; Vella, A.; et al. In vitro effect of clarithromycin and alginate lyase against Helicobacter pylori biofilm. Biotechnol. Prog. 2016, 32, 1584-1591. [CrossRef] [PubMed]

35. Yonezawa, H.; Osaki, T.; Hanawa, T.; Kurata, S.; Ochiai, K.; Kamiya, S. Impact of Helicobacter pylori Biofilm Formation on Clarithromycin Susceptibility and Generation of Resistance Mutations. PLoS ONE 2013, 8, e73301. [CrossRef] [PubMed]

36. Mori, M.; Suzuki, H.; Suzuki, M.; Kai, A.; Miura, S.; Ishii, H. Catalase and superoxide dismutase secreted from Helicobacter pylori. Helicobacter 1997, 2, 100-105. [CrossRef]

37. Lamarque, D.; Moran, A.P.; Szepes, Z.; Delchier, J.C.; Whittle, B.J.R. Cytotoxicity associated with induction of nitric oxide synthase in rat duodenal epithelial cells in vivo by lipopolysaccharide of Helicobacter pylori: Inhibition by superoxide dismutase. Brit. J. Pharmacol. 2000, 130, 1531-1538. [CrossRef]

38. Bereswill, S.; Neuner, O.; Strobel, S.; Kist, M. Identification and molecular analysis of superoxide dismutase isoforms in Helicobacter pylori. Fems Microbiol. Lett. 2000, 183, 241-245. [CrossRef]

39. Seyler, R.W.; Olson, J.W.; Maier, R.J. Superoxide dismutase-deficient mutants of Helicobacter pylori are hypersensitive to oxidative stress and defective in host colonization. Infect. Immun. 2001, 69, 4034-4040. [CrossRef]

40. Chang, W.L.; Yeh, Y.C.; Sheu, B.S. The impacts of H. pylori virulence factors on the development of gastroduodenal diseases. J. Biomed. Sci. 2018, 25, 68. [CrossRef]

41. Qureshi, N.; Li, P.; Gu, Q. Probiotic therapy in Helicobacter pylori infection: A potential strategy against a serious pathogen? Appl. Microbiol. Biotechnol. 2019, 103, 1573-1588. [CrossRef] [PubMed]

42. Nejati, S.; Karkhah, A.; Darvish, H.; Validi, M.; Ebrahimpour, S.; Nouri, H.R. Influence of Helicobacter pylori virulence factors CagA and VacA on pathogenesis of gastrointestinal disorders. Microb. Pathog. 2018, 117, 43-48. [CrossRef] [PubMed]

43. Sterbenc, A.; Jarc, E.; Poljak, M.; Homan, M. Helicobacter pylori virulence genes. World J. Gastroenterol. 2019, 25, 4870-4884. [CrossRef] [PubMed]

44. Hatakeyama, M. Helicobacter pylori CagA and gastric cancer: A paradigm for hit-and-run carcinogenesis. Cell Host Microbe 2014, 15, 306-316. [CrossRef]

45. McClain, M.S.; Beckett, A.C.; Cover, T.L. Helicobacter pylori vacuolating toxin and gastric cancer. Toxins 2017, 9, 316. [CrossRef]

46. Chauhan, N.; Tay, A.C.Y.; Marshall, B.J.; Jain, U. Helicobacter pylori VacA, a distinct toxin exerts diverse functionalities in numerous cells: An overview. Helicobacter 2019, 24, e12544. [CrossRef]

47. Kabamba, E.T.; Tuan, V.P.; Yamaoka, Y. Genetic populations and virulence factors of Helicobacter pylori. Infect. Genet. Evol. 2018, 60, 109-116. [CrossRef]

48. Ansari, S.; Yamaoka, Y. Survival of Helicobacter pylori in gastric acidic territory. Helicobacter 2017, 22, e12386. [CrossRef]

49. Souza, M.D.J.; De Moraes, J.A.; Da Silva, V.N.; Helal-Neto, E.; Uberti, A.F.; Scopel-Guerra, A.; Olivera-Severo, D.; Carlini, C.R.; Barja-Fidalgo, C. Helicobacter pylori urease induces pro-inflammatory effects and differentiation of human endothelial cells: Cellular and molecular mechanism. Helicobacter 2019, 24, e12573. [CrossRef]

50. Talebi Bezmin Abadi, A. Helicobacter pylori treatment: New perspectives using current experience. J. Glob. Antimicrob. Resist. 2017, 8, 123-130. [CrossRef]

51. Eslami, M.; Yousefi, B.; Kokhaei, P.; Jazayeri Moghadas, A.; Sadighi Moghadam, B.; Arabkari, V.; Niazi, Z. Are probiotics useful for therapy of Helicobacter pylori diseases? Comp. Immunol. Microbiol. Infect. Dis. 2019, 64, 99-108. [CrossRef] [PubMed]

52. Graham, D.Y. Helicobacter pylori update: Gastric cancer, reliable therapy, and possible benefits. Gastroenterology 2015, 148, 719-731. [CrossRef] [PubMed]

53. Graham, D.Y.; Lu, H.; Dore, M.P. Relative potency of proton-pump inhibitors, Helicobacter pylori therapy cure rates, and meaning of double-dose PPI. Helicobacter 2019, 24, e12554. [CrossRef] [PubMed]

54. Hu, Y.; Zhu, Y.; Lu, N.H. Novel and Effective Therapeutic Regimens for Helicobacter pylori in an Era of Increasing Antibiotic Resistance. Front. Cell Infect. Microbiol. 2017, 7, 168. [CrossRef] [PubMed] 
55. Alba, C.; Blanco, A.; Alarcon, T. Antibiotic resistance in Helicobacter pylori. Curr. Opin. Infect. Dis. 2017, 30, 489-497. [CrossRef] [PubMed]

56. Wu, L.; Wang, Z.; Sun, G.; Peng, L.; Lu, Z.; Yan, B.; Huang, K.; Yang, Y. Effects of anti-H. pylori triple therapy and a probiotic complex on intestinal microbiota in duodenal ulcer. Sci. Rep. 2019, 9, 1-11. [CrossRef]

57. Olekhnovich, E.I.; Manolov, A.I.; Samoilov, A.E.; Prianichnikov, N.A.; Malakhova, M.V.; Tyakht, A.V.; Pavlenko, A.V.; Babenko, V.V.; Larin, A.K.; Kovarsky, B.A.; et al. Shifts in the human gut microbiota structure caused by quadruple Helicobacter pylori eradication therapy. Front. Microbiol. 2019, 10, 1902. [CrossRef]

58. Cornejo-Pareja, I.; Martín-Núñez, G.; Roca-Rodríguez, M.; Cardona, F.; Coin-Aragüez, L.; Sánchez-Alcoholado, L.; Gutiérrez-Repiso, C.; Muñoz-Garach, A.; Fernández-García, J.; Moreno-Indias, I.; et al. H. pylori Eradication treatment alters gut microbiota and GLP-1 secretion in humans. J. Clin. Med. 2019, 8, 451. [CrossRef]

59. Imhann, F.; Bonder, M.J.; Vich Vila, A.; Fu, J.; Mujagic, Z.; Vork, L.; Tigchelaar, E.F.; Jankipersadsing, S.A.; Cenit, M.C.; Harmsen, H.J.M.; et al. Proton pump inhibitors affect the gut microbiome. Gut 2016, 65, 740-748. [CrossRef]

60. Jackson, M.A.; Goodrich, J.K.; Maxan, M.-E.; Freedberg, D.E.; Abrams, J.A.; Poole, A.C.; Sutter, J.L.; Welter, D.; Ley, R.E.; Bell, J.T.; et al. Proton pump inhibitors alter the composition of the gut microbiota. Gut 2016, 65, 749-756. [CrossRef]

61. Chen, Y.H.; Tsai, W.H.; Wu, H.Y.; Chen, C.Y.; Yeh, W.L.; Chen, Y.H.; Hsu, H.Y.; Chen, W.W.; Chen, Y.W.; Chang, W.W.; et al. Probiotic Lactobacillus spp. act Against Helicobacter pylori-induced Inflammation. J. Clin. Med. 2019, 8, 90. [CrossRef] [PubMed]

62. Zhao, K.; Xie, Q.; Xu, D.; Guo, Y.; Tao, X.; Wei, H.; Wan, C. Antagonistics of Lactobacillus plantarum ZDY2013 against Helicobacter pylori SS1 and its infection in vitro in human gastric epithelial AGS cells. J. Biosci. Bioeng. 2018, 126, 458-463. [CrossRef] [PubMed]

63. Sun, L.; Zhao, H.; Liu, L.; Wu, X.; Gao, Q.; Zhao, Y. Effects of Lactobacillus on the inhibition of Helicobacter pylori growth. Biotechnol. Biotechnol. Equip. 2018, 32, 1533-1540. [CrossRef]

64. Aiba, Y.; Nakano, Y.; Koga, Y.; Takahashi, K.; Komatsu, Y. A highly acid-resistant novel strain of Lactobacillus johnsonii No. 1088 has antibacterial activity, including that against Helicobacter pylori, and inhibits gastrin-mediated acid production in mice. Microbiologyopen 2015, 4, 465-474. [CrossRef] [PubMed]

65. Aiba, Y.; Ishikawa, H.; Tokunaga, M.; Komatsu, Y. Anti-Helicobacter pylori activity of non-living, heat-killed form of lactobacilli including Lactobacillus johnsonii No.1088. FEMS Microbiol. Lett. 2017, 364. [CrossRef] [PubMed]

66. Poppi, L.B.; Rivaldi, J.D.; Coutinho, T.S.; Astolfi-Ferreira, C.S.; Ferreira, A.J.P.; Mancilha, I.M. Effect of Lactobacillus sp isolates supernatant on Escherichia coli O157:H7 enhances the role of organic acids production as a factor for pathogen control. Pesqui. Veterinária Bras. 2015, 35, 353-359. [CrossRef]

67. Zheng, P.X.; Fang, H.Y.; Yang, H.B.; Tien, N.Y.; Wang, M.C.; Wu, J.J. Lactobacillus pentosus strain LPS16 produces lactic acid, inhibiting multidrug-resistant Helicobacter pylori. J. Microbiol. Immunol. Infect. 2016, 49, 168-174. [CrossRef]

68. Lesbros-Pantoflickova, D.; Corthesy-Theulaz, I.; Blum, A.L. Helicobacter pylori and probiotics. J. Nutr. 2007, 137, 812S-818S. [CrossRef]

69. Batdorj, B.; Trinetta, V.; Dalgalarrondo, M.; Prevost, H.; Dousset, X.; Ivanova, I.; Haertle, T.; Chobert, J.M. Isolation, taxonomic identification and hydrogen peroxide production by Lactobacillys delbrueckii subsp lactis T31, isolated from Mongolian yoghurt: Inhibitory activity on food-borne pathogens fool-borne pathogens. J. Appl. Microbiol. 2007, 103, 584-593. [CrossRef]

70. Kim, N.-N.; Kim, W.J.; Kang, S.-S. Anti-biofilm effect of crude bacteriocin derived from Lactobacillus brevis DF01 on Escherichia coli and Salmonella Typhimurium. Food Control 2019, 98, 274-280. [CrossRef]

71. Kim, T.S.; Hur, J.W.; Yu, M.A.; Cheigh, C.I.; Kim, K.N.; Hwang, J.K.; Pyun, Y.R. Antagonism of Helicobacter pylori by bacteriocins of lactic acid bacteria. J. Food Prot. 2003, 66, 3-12. [CrossRef] [PubMed]

72. Boyanova, L.; Gergova, G.; Markovska, R.; Yordanov, D.; Mitov, I. Bacteriocin-like inhibitory activities of seven Lactobacillus delbrueckii subsp. bulgaricus strains against antibiotic susceptible and resistant Helicobacter pylori strains. Lett. Appl. Microbiol. 2017, 65, 469-474. [CrossRef] [PubMed]

73. Urrutia-Baca, V.H.; Escamilla-Garcia, E.; de la Garza-Ramos, M.A.; Tamez-Guerra, P.; Gomez-Flores, R.; Urbina-Rios, C.S. In Vitro antimicrobial activity and downregulation of virulence gene expression on Helicobacter pylori by reuterin. Probiotics Antimicrob. Proteins 2018, 10, 168-175. [CrossRef] [PubMed] 
74. Mukai, T.; Asasaka, T.; Sato, E.; Mori, K.; Matsumoto, M.; Ohori, H. Inhibition of binding of Helicobacter pylori to the glycolipid receptors by probiotic Lactobacillus reuteri. Fems Immunol. Med Microbiol. 2002, 32, 105-110. [CrossRef]

75. De Klerk, N.; Maudsdotter, L.; Gebreegziabher, H.; Saroj, S.D.; Eriksson, B.; Eriksson, O.S.; Roos, S.; Lindén, S.; Sjölinder, H.; Jonsson, A.-B. Lactobacilli reduce Helicobacter pylori attachment to host gastric epithelial cells by inhibiting adhesion gene expression. Infect. Immun. 2016, 84, 1526-1535. [CrossRef]

76. Sakarya, S.; Gunay, N. Saccharomyces boulardii expresses neuraminidase activity selective for alpha2,3-linked sialic acid that decreases Helicobacter pylori adhesion to host cells. APMIS 2014, 122, 941-950. [CrossRef]

77. Byrd, J.C.; Yunker, C.K.; Xu, Q.S.; Sternberg, L.R.; Bresalier, R.S. Inhibition of gastric mucin synthesis by Helicobacter pylori. Gastroenterology 2000, 118, 1072-1079. [CrossRef]

78. Suez, J.; Zmora, N.; Segal, E.; Elinav, E. The pros, cons, and many unknowns of probiotics. Nat. Med. 2019, 25, 716-729. [CrossRef]

79. Yang, Y.-J.; Chuang, C.-C.; Yang, H.-B.; Lu, C.-C.; Sheu, B.-S. Lactobacillus acidophilus ameliorates H. pylori-induced gastric inflammation by inactivating the Smad7 and NFKB pathways. BMC Microbiol. 2012, 12, 38. [CrossRef]

80. Thiraworawong, T.; Spinler, J.K.; Werawatganon, D.; Klaikeaw, N.; Venable, S.F.; Versalovic, J.; Tumwasorn, S. Anti-inflammatory properties of gastric-derived Lactobacillus plantarum XB7 in the context of Helicobacter pylori infection. Helicobacter 2014, 19, 144-155. [CrossRef]

81. Quigley, E.M.M. Prebiotics and probiotics in digestive health. Clin. Gastroenterol. Hepatol. 2019, 17, 333-344. [CrossRef] [PubMed]

82. Gotteland, M.; Poliak, L.; Cruchet, S.; Brunser, O. Effect of regular ingestion of Saccharomyces boulardii plus inulin or Lactobacillus acidophilus LB in children colonized by Helicobacter pylori. Acta Paediatr. 2005, 94, 1747-1751. [CrossRef] [PubMed]

83. Fonseca, J.D.; Fernandes, C.C.; Cunha, L.F.; Zung, S. Efficacy and Safety of Lactobacillus reuteri in Helicobacter pylori Infection. Gastroenterology 2019, 156, S531-S532. [CrossRef]

84. Sykora, J.; Valeckova, K.N.; Amlerova, J.; Siala, K.; Dedek, P.; Watkins, S.; Varvarovska, J.; Stozicky, F.; Pazdiora, P.; Schwarz, J. Effects of a specially designed fermented milk product containing probiotic Lactobacillus casei DN-114 001 and the eradication of H-pylori in children-A prospective randomized double-blind study. J. Clin. Gastroenterol. 2005, 39, 692-698. [CrossRef]

85. Deguchi, R.; Nakaminami, H.; Rimbara, E.; Noguchi, N.; Sasatsu, M.; Suzuki, T.; Matsushima, M.; Koike, J.; Igarashi, M.; Ozawa, H.; et al. Effect of pretreatment with Lactobacillus gasseri OLL2716 on first-line Helicobacter pylori eradication therapy. J. Gastroenterol. Hepatol. 2012, 27, 888-892. [CrossRef]

86. Sachdeva, A.; Nagpal, J. Effect of fermented milk-based probiotic preparations on Helicobacter pylori eradication: A systematic review and meta-analysis of randomized-controlled trials. Eur. J. Gastroenterol. Hepatol. 2009, 21, 45-53. [CrossRef]

87. McNicholl, A.G.; Molina-Infante, J.; Lucendo, A.J.; Calleja, J.L.; Pérez-Aisa, Á.; Modolell, I.; Aldeguer, X.; Calafat, M.; Comino, L.; Ramas, M.; et al. Probiotic supplementation with Lactobacillus plantarum and Pediococcus acidilactici for Helicobacter pylori therapy: A randomized, double-blind, placebo-controlled trial. Helicobacter 2018, 23, e12529. [CrossRef]

88. Marcusson, L.L.; Olofsson, S.K.; Lindgren, P.K.; Cars, O.; Hughes, D. Mutant prevention concentrations of ciprofloxacin for urinary tract infection isolates of Escherichia coli. J. Antimicrob. Chemother. 2005, 55, 938-943. [CrossRef]

89. Feng, Z.-H.; Fan, L.; Yang, J.; Huo, X.-Y.; Guo, Y.; Zhang, Y.; Lan, C.-H. Mutant selection window of clarithromycin for clinical isolates of Helicobacter pylori. BMC Microbiol. 2019, 19, 176. [CrossRef]

90. Brooks, B.D.; Brooks, A.E. Therapeutic strategies to combat antibiotic resistance. Adv. Drug Deliv. Rev. 2014, 78, 14-27. [CrossRef]

91. Hemaiswarya, S.; Kruthiventi, A.K.; Doble, M. Synergism between natural products and antibiotics against infectious diseases. Phytomedicine 2008, 15, 639-652. [CrossRef] [PubMed]

92. Caesar, L.K.; Cech, N.B. Synergy and antagonism in natural product extracts: When $1+1$ does not equal 2. Nat. Prod. Rep. 2019, 36, 869-888. [CrossRef] [PubMed]

93. Jia, J.; Zhu, F.; Ma, X.; Cao, Z.W.; Li, Y.X.; Chen, Y.Z. Mechanisms of drug combinations: Interaction and network perspectives. Nat. Rev. Drug Discov. 2009, 8, 111-128. [CrossRef] [PubMed] 
94. Soleymanzadeh Moghadam, S.; Khodaii, Z.; Fathi Zadeh, S.; Ghooshchian, M.; Fagheei Aghmiyuni, Z.; Mousavi Shabestari, T. Synergistic or antagonistic effects of probiotics and antibiotics-alone or in combinationon antimicrobial-resistant Pseudomonas aeruginosa isolated from burn wounds. Arch. Clin. Infect. Dis. 2018, 13, e63121. [CrossRef]

95. Yang, J.; Yang, H. Effect of Bifidobacterium breve in Combination With Different Antibiotics on Clostridium difficile. Front. Microbiol. 2018, 9, 2953. [CrossRef]

96. De La Fuente-Núñez, C.; Reffuveille, F.; Fernández, L.; Hancock, R.E. Bacterial biofilm development as a multicellular adaptation: Antibiotic resistance and new therapeutic strategies. Curr. Opin. Microbiol. 2013, 16, 580-589. [CrossRef]

97. Rizzato, C.; Torres, J.; Kasamatsu, E.; Camorlinga-Ponce, M.; Bravo, M.M.; Canzian, F.; Kato, I. Potential Role of Biofilm Formation in the Development of Digestive Tract Cancer With Special Reference to Helicobacter pylori Infection. Front. Microbiol. 2019, 10, 846. [CrossRef]

98. Ge, X.; Cai, Y.; Chen, Z.; Gao, S.; Geng, X.; Li, Y.; Li, Y.; Jia, J.; Sun, Y. Bifunctional enzyme spot is involved in biofilm formation of Helicobacter pylori with multidrug resistance by upregulating efflux pump Hp1174 (gluP). Antimicrob. Agents Chemother. 2018, 62, e00957-18. [CrossRef]

99. Bińkowska, A.; Biernat, M.; Duś, I.; Gościniak, G. The role of biofilm formation in pathogenesis of Helicobacter pylori infections. Prz. Gastroenterol. 2013, 1, 27-30. [CrossRef]

100. Hathroubi, S.; Zerebinski, J.; Ottemann, K.M. Helicobacter pylori biofilm involves a multigene stress-biased response, including a structural role for flagella. mBio 2018, 9, e01973-18. [CrossRef]

101. Cammarota, G.; Branca, G.; Ardito, F.; Sanguinetti, M.; Ianiro, G.; Cianci, R.; Torelli, R.; Masala, G.; Gasbarrini, A.; Fadda, G.; et al. Biofilm demolition and antibiotic treatment to eradicate resistant Helicobacter pylori: A Clinical Trial. Clin. Gastroenterol. Hepatol. 2010, 8, 817-820. [CrossRef] [PubMed]

102. Song, H.; Zhang, J.; Qu, J.; Liu, J.; Yin, P.; Zhang, G.; Shang, D. Lactobacillus rhamnosus GG microcapsules inhibit Escherichia coli biofilm formation in coculture. Biotechnol. Lett. 2019, 41, 1007-1014. [CrossRef] [PubMed]

103. Merino, L.; Trejo, F.M.; De Antoni, G.; Golowczyc, M.A. Lactobacillus strains inhibit biofilm formation of Salmonella sp. isolates from poultry. Food Res. Int. 2019, 123, 258-265. [CrossRef] [PubMed]

104. Jung, S.; Park, O.J.; Kim, A.R.; Ahn, K.B.; Lee, D.; Kum, K.Y.; Yun, C.H.; Han, S.H. Lipoteichoic acids of lactobacilli inhibit Enterococcus faecalis biofilm formation and disrupt the preformed biofilm. J. Microbiol. 2019, 57, 310-315. [CrossRef] [PubMed]

105. Gonzalez Moreno, M.; Trampuz, A.; Di Luca, M. Synergistic antibiotic activity against planktonic and biofilm-embedded Streptococcus agalactiae, Streptococcus pyogenes and Streptococcus oralis. J. Antimicrob. Chemother. 2017, 72, 3085-3092. [CrossRef]

106. Butel, M.J. Probiotics, gut microbiota and health. Med. Mal. Infect. 2014, 44, 1-8. [CrossRef]

107. Rooks, M.G.; Garrett, W.S. Gut microbiota, metabolites and host immunity. Nat. Rev. Immunol. 2016, 16, 341-352. [CrossRef]

108. Nicholson, J.K.; Holmes, E.; Kinross, J.; Burcelin, R.; Gibson, G.; Jia, W.; Pettersson, S. Host-gut microbiota metabolic interactions. Science 2012, 336, 1262-1267. [CrossRef]

109. Clemente, J.C.; Ursell, L.K.; Parfrey, L.W.; Knight, R. The impact of the gut microbiota on human health: An integrative view. Cell 2012, 148, 1258-1270. [CrossRef]

110. Kienesberger, S.; Laura Livanos, A.; Zhang, X.-S.; Chung, J.; Guillermo, I.; Gorkiewicz, G.; Ellen, L.; Martin, I. Helicobacter pylori infection affects local and distant microbial populations and host responses. Cell Rep. 2016, 14, 1395-1407. [CrossRef]

111. Shin, C.M.; Kim, N.; Lee, D.H. Changes of gastric corpus microbiota after Helicobacter Pylori eradication: A long term follow up study. Gastroenterology 2019, 156, S535. [CrossRef] 
112. Gareau, M.G.; Sherman, P.M.; Walker, W.A. Probiotics and the gut microbiota in intestinal health and disease. Nat. Rev. Gastroenterol. Hepatol. 2010, 7, 503-514. [CrossRef] [PubMed]

113. Gunathilake, M.N.; Lee, J.; Choi, I.J.; Kim, Y.-I.; Ahn, Y.; Park, C.; Kim, J. Assoc. between the relative abundance of gastric microbiota and the risk of gastric cancer: A case-control study. Sci. Rep. 2019, 9, 1-11. [CrossRef] [PubMed]

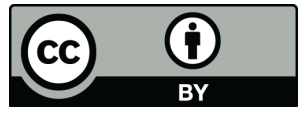

(C) 2020 by the authors. Licensee MDPI, Basel, Switzerland. This article is an open access article distributed under the terms and conditions of the Creative Commons Attribution (CC BY) license (http://creativecommons.org/licenses/by/4.0/). 